\title{
Problematika Penyaluran Bantuan Langsung Tunai Dana Desa (BLT DD) Tahun 2020
}

\author{
Suryaningsih Aseh ${ }^{1}$, Tengku Fahrul Gafar ${ }^{\mathbf{2}}$ dan Zamhasari Zamhasari ${ }^{\mathbf{3}}$ \\ ${ }^{1}$ Sekolah Tinggi Ilmu Sosial dan Ilmu Politik (STISIP) Imam Bonjol, Padang, Indonesia \\ ${ }^{2,3}$ Universitas Abdurrab, Pekanbaru, Indonesia \\ aseh2309@gmail.com
}

\begin{abstract}
The priority for using the Village Fund in 2020 has changed along with the existence of financial policies for handling the dissemination of COVID-19 in the village. Based on this, the Village Fund (DD) is prioritized used for handling the COVID-19, one of the priorities is for Direct Cash Assistance (BLT). In its implementation, the Direct Cash Assistance of the Village Fund (BLT-DD) policy has caused many polemics. Based on these problems, the purpose of this paper is to explore the factors that influence the implementation performance of BLT DD distribution. The method used in this research is qualitative exploratory. Data collection was conducted by means of observation, interviews, and literature study. The results displayed that the factors affecting the implementation performance were caused by; first, the factor of clarity of policy content, village volunteers found it difficult to collect data on BLT-DD Beneficiary Families (KPM) due to the criteria set fluctuated and the number of KPM was limited based on the percentage of The Village Funds received by the village. The second, the Regulatory Inconsistency Factor. The changing regulations made it difficult for the village government to implement the BLT-DD distribution. Third, technical factors. The process of disbursing the BLT-DD was long enough to prevent The Village Government from delivering BLT-DD on time.
\end{abstract}

Keywords: Village, BLT, Village fund, COVID-19

\section{Pendahuluan}

Kasus pertama COVID-19 di Indonesia diumumkan oleh Presiden Jokowi pada hari senin tanggal 2 Maret 2020 (Inayah, 2020). Dijelaskan oleh Presiden bahwasannya ada 2 orang yang terkonfirmasi positif COVID-19 di Indonesia. Sejak diumumkannya kasus covid 19 tersebut diambillah berbagai kebijakan agar kasus COVID-19 ini tidak semakin bertambah. Kebijakan tersebut antara lain melarang semua penerbangan dari dan ke China; menghentikan pemberian visa bagi warga negara China untuk melakukan perjalanan ke Indonesia; membatasi perjalanan dari dan ke beberapa negara seperti Korea Selatan, Italia, dan Iran; meliburkan sekolah, kampus, termasuk beberapa kantor pemerintahan dan perusahaan swasta; hingga menutup pusatpusat hiburan (Agustino, 2020). Namun kebijakan yang diambil pemerintah tersebut dianggap terlambat karena kasus COVID-19 terus mengalami peningkatan hingga akhir Maret 2020 tercatat jumlah pasien yang terkonfirmasi positif COVID-19 sebanyak 1.414 kasus (Nugraheny, 2020).

Pandemi COVID-19 telah berdampak kepada perlambatan pertumbuhan ekonomi nasional, penurunan penerimaan negara, dan peningkatan belanja negara melalui pembiayaan. Untuk mengatasi hal ini pemerintah kemudian mengeluarkan Peraturan Pemerintah Pengganti Undangundang (Perppu) No. 1 Tahun 2020 Tentang Kebijakan Keuangan Negara dan Stabilitas Sistem keuangan Untuk Penanganan Pandemi Corona Virus Disease 2019 (COVID-19) dan/atau Dalam Rangka Menghadapi Ancaman yang Membahayakan Perekonomian Nasional dan/atau Stabilitas Sistem Keuangan pada tanggal 31 Maret 2020.

Adapun kebijakan yang diambil oleh pemerintah untuk mengatasi defisit anggaran dalam neraca Anggaran 
Pendapatan Belanja Negara (APBN) melalui Perppu ini adalah dengan melakukan pemangkasan hingga pengutamaan (refocusing) pelaksanaan kegiatan ditiap lembaga/kementrian, pemerintahan daerah, dan pemerintahan desa (Amiruddin, 2020). Menindaklanjuti Perppu No. 1 tahun 2020 ini, Kementrian Desa Pembangunan Daerah Tertinggal dan Transmigrasi (Kemendes PDTT) mengambil kebijakan dengan melakukan perubahan atas prioritas penggunaan Dana Desa tahun 2020. Adapun perubahan kebijakan prioritas penggunaan dana desa yang termaktub dalam Peraturan Menteri Desa No. 6 tahun 2020 tentang Perubahan Peraturan Menteri Desa Pembangunan Daerah Tertinggal dan Transmigrasi (Permendesa) No. 11 Tahun 2019 Tentang Prioritas Penggunaan Dana Desa Tahun 2020 adalah untuk Pertama, Pencegahan dan penanganan COVID-19; Kedua, Padat Karya Tunai Desa (PKTD); Ketiga, Bantuan Langsung Tunai Dana Desa (BLT-DD).

Tidak hanya Kementrian Desa yang menanggapi Perppu No. 1/2020 ini, Kementrian Keuangan dan Kementrian Dalam Negeri juga mengeluarkan kebijakan terkait dengan penggunaan dana desa. Kebijakan kedua kementrian tersebut mendukung kebijakan dari Kementrian Desa. Malalui Peraturan Menteri Keuangan No. 40/PMK.07/2020 tentang Perubahan Atas Peraturan Menteri Keuangan No. 205/PMK.07/2019 tentang Pengelolaan Dana Desa dalam pasal 24A diatur bahwasannya penyaluran Dana Desa tahap 1 disalurkan secara bulanan dalam kurun waktu 3 bulan dengan salah satu syarat pencairan adanya Peraturan Kepala Desa mengenai penetapan keluarga penerima manfaat BLT Desa. Sedangkan Instruksi Menteri Dalam Negeri No. 3/2020 tentang Penanggulangan COVID-19 di Desa Melalui Anggaran dan Pendapatan Belanja Desa menekankan pada desa untuk segera melakukan perubahan dan/atau membelanjakan APBDesa untuk penanggulangan COVID-19 yang salah satunya dengan Pemberian Bantuan Langsung Tunai (BLT).

Selama masa pandemi COVID-19 ini ada 7 (tujuh) skema bantuan pemerintah dalam bentuk jaring pengaman sosial, yakni bantuan sembako, bantuan sosial tunai, BLT Dana Desa, listrik gratis, kartu pra kerja, subsidi gaji karyawan, dan BLT usaha mikro kecil. Permasalahan yang kemudian muncul dari penyaluran bantuan sosial ini adalah masalah alokasi anggaran yang berbeda ditiap kementrian, masalah data penerima bantuan yang tidak terintegrasi, dan masalah sistem penyaluran bantuan tersebut (Rahmansyah et al., 2020). Padahal seharusnya, pelaksanaan ini harus transparansi dalam pelaksanaa pemerintah karena apapun yang berkaitan dengan public haruslah terukur dan dapat bertanggungjawab secara terbuka (Yandra, 2016).

Khusus untuk BLT Dana Desa berbagai kajian juga telah dilakukan, seperti penelitian Carly tentang efektifitas bantuan langsung tunai dana desa bagi masyarakat miskin. Hasil penelitiannya menunjukkan bahwa efektivitas program ini sangat dirasakan oleh masyarakat miskin (Maun, 2020). Penelitian tentang dampak penggunaan dana desa dalam masa pandemi COVID-19 tahun 2020 juga telah dilakukan oleh Andika Sari dan kawan-kawan. Salah satu hasil penelitiannya adalah keterlambatan penyaluran BLT dana desa kepada masyarakat yang terkena dampak pandemi COVID-19 yang dikarenakan adanya kebingungan kebijakan antara surat edaran Menteri Desa No. 8 Tahun 2020 dan Instruksi Menteri Dalam Negeri No. 3 Tahun 2020 (Sari et al., 2020). Selain itu, penelitian tentang transparansi dalam pelaksanaan Bantuan Langsung Tunai (BLT) Dana Desa dilakukan oleh Tioma dan Nanang. Hasil penelitiannya menunjukkan bahwa dalam implementasinya terjadi pro dan kontra bagi penerimanya karena tidak adanya informasi yang benar kepada publik (Hariandja \& Budiman, 2020). Ira Novianty dan kawankawan juga melakukan penelitian terkait dengan Praktik Penganggaran dan 
Penyaluran Bantuan dana Desa di Masa Pandemi COVID-19. Hasil penelitian menunjukkan banyaknya jenis bantuan dan sumber bantuan yang diterima warga tidak didukung oleh sistem informasi jaring pengaman sosial yang terintegrasi di tingkat pusat, provinsi, kabupaten, dan desa sehingga perubahan anggaran yang fokusnya pada bantuan dana desa menjadi hal yang sangat sulit dialokasikan secara merata dikarenakan keterbatasan anggaran pemerintah desa (Novianty et al., 2020).

Dari beberapa kajian yang telah dilakukan tersebut terlihat bahwasannya problematika Bantuan Langsung Tunai (BLT) adalah terkait dengan indikator penerima BLT, transparansi penetapan penerima BLT, dan ketepatan waktu distribusi BLT. Kajian yang secara khusus melihat problematika penyaluran BLT Dana Desa belum ada. Peneliti menganggap Hal ini penting dilakukan untuk melihat apa saja problematika penyaluran BLT Dana Desa tersebut ditinjau dari teori implementasi kebijakan.

\section{Metode}

Metode yang digunakan dalam penelitian ini adalah kualitatif dengan pendekatan eksploratif. Penelitian eksploratif ini digunakan untuk mengidentifikasi sifat-sifat suatu gejala atau peristiwa (Silalahi, 2010). Dengan menggunakan metode ini peneliti dapat memahami makna dibalik data yang tampak dari fenomena penyaluran BLT Dana Desa.

Teknik pengumpulan data dalam penelitian ini dilakukan dengan observasi (pengamatan), interview (wawancara), dan studi kepustakaan. Pengumpulan data dengan observasi dan wawancara penulis lakukan di Kabupaten Lima Puluh Kota Provinsi Sumatera Barat. Dengan observasi di lapangan dan wawancara penulis lebih dapat memahami konteks data dan pengalaman langsung terkait dengan penyaluran BLT Dana Desa (Sugiyono, 2005).

\section{Hasil dan Pembahasan}

Dari hasil penelitian yang telah dilakukan oleh beberapa peneliti terlihat bahwasannya ada beberapa faktor penyebab keterlambatan penyaluran BLT Dana Desa, yakni adanya kebingungan kebijakan yang dikeluarkan oleh pemerintah pusat, tidak adanya keterbukaan informasi publik terkait dengan penerima BLT DD sehingga menimbulkan konflik di masyarakat, dan tidak adanya sistem informasi jaring pengaman sosial yang terintegrasi dari tingkat pusat, provinsi, dan kabupaten. Dari beberapa hasil studi kepustakaan dan hasil observasi lapangan maka faktor-faktor yang mempengaruhi kinerja implementasi dapat dikelompokkan sebagai berikut:

\subsection{Faktor Kejelasan Isi Kebijakan}

Salah satu variabel yang mempengaruhi keberhasilan implementasi menurut Mazmanian dan Sabatier (1983) adalah karakteristik kebijakan. Indikator untuk melihat karakteristik kebijakan ini adalah adanya kejelasan isi kebijakan. Semakin jelas dan rinci sebuah kebijakan maka akan semakin mudah untuk diimplementasikan. Sebaliknya, ketidakjelasan isi kebijakan akan memunculkan distorsi dalam implementasi kebijakan (Subarsono, 2008).

Kebijakan penyaluran BLT Dana Desa untuk penanggulana COVID-19 diatur dengan banyak regulasi. Regulasi yang mengatur tentang BLT Dana Desa selalu berubah, terlihat bahwa di bulan April 2020 ada 5 (lima) regulasi yang dikeluarkan, yakni pertama, Peraturan Menteri Desa PDTT No. 6 Tahun 2020 tentang Perubahan Atas Peraturan Menteri Desa, Pembangunan Daerah Tertinggal, dan Transmigrasi No. 11 Tahun 2019 Tentang Prioritas Penggunaan Dana Desa Tahun 2020; Kedua, Surat menteri Desa PDTT No. 1261/PRI.00/IV/2020 perihal pemberitahuan; Ketiga, Surat Direktorat Jendral Pembangunan dan Pemberdayaan Masyarakat No. 9/PRI.00/IV/2020 perihal petunjuk teknis pendataan keluarga calon penerima BLT Dana Desa; Keempat, Surat Direktorat Jendral Pembangunan dan Pemberdayaan Masyarakat No. 
10/PRI.00/IV/2020 perihal penegasan petunjuk teknis pendataan keluarga calon penerima BLT Dana Desa; dan Kelima, Surat Direktorat Jendral Pembangunan dan Pemberdayaan Masyarakat No. 12/PRI.00/IV/2020 perihal penegasan BLT Dana Desa. Dari beberapa regulasi tersebut, isi kebijakan yang menjadi polemik dilapangan adalah terkait dengan sasaran penerima dan mekanisme penyaluran BLT Dana Desa.

\subsubsection{Sasaran Penerima BLT Dana Desa}

BLT Dana Desa diatur melalui Pasal 8A ayat (2), (3), dan (4) Peraturan Menteri Desa (Permendesa) No. 6 tahun 2020 tentang Perubahan Atas Peraturan Menteri Desa, Pembangunan Daerah Tertinggal, dan Transmigrasi No. 11 Tahun 2019 Tentang Prioritas Penggunaan Dana Desa Tahun 2020. Dalam pasal tersebut disebutkan bahwa penanganan COVID-19 dapat berupa BLT Dana Desa kepada keluarga miskin yang kehilangan mata pencaharian atau pekerjaan, belum terdata menerima Program keluarga Harapan (PKH), Bantuan Pangan Non Tunai (BPNT), dan kartu pra kerja serta mempunyai anggota keluarga yang rentan sakit menahun/kronis

Dalam lampiran II Permendesa ini dijelaskan lebih lanjut tentang (a) sasaran penerima BLT; (b) mekanisme pendataan; (c) metode dan mekanisme penyaluran; (d) jangka waktu dan besaran pemberian BLT Dana Desa; (e) monitoring dan evaluasi; (f) penanggungjawab penyaluran BLT DD; dan (g) mekanisme perubahan Anggaran Pendapatan dan Belanja Desa (APBDes).

Pengaturan lebih lanjut mengenai BLT Dana Desa diatur melalui Surat Menteri Desa PDTT No. 1261/PRI.00/IV/2020 tanggal 14 April 2020. Dalam surat tersebut sasaran penerima BLT-Dana Desa adalah keluarga miskin non PKH atau Bantuan Pangan Non Tunai (BPNT) yang kehilangan mata pencaharian, belum terdata, dan mempunyai anggota keluarga yang rentan sakit menahun/sakit kronis. Keluarga miskin yang dimaksud harus memenuhi kriteria sebagai berikut:

Tabel 1

Kriteria Keluarga Miskin

\begin{tabular}{cl}
\hline No & \multicolumn{1}{c}{ Kriteria Keluarga Miskin } \\
\hline 1 & Luas lantai <8m2/orang \\
2 & Lantai tanah/bambu/kayu murah \\
3 & Dinding bambu/rumbia/kayu murah/tembok tanpa plester \\
4 & Buang air besar tanpa fasilitas/bersama orang lain \\
5 & Penerangan tanpa listrik \\
6 & Air minum dari sumur/mata air tidak terlindung/sungai/air hujan \\
7 & Bahan bakar kayu bakar/arang/minyak tanah \\
8 & Konsumsi daging/susu/ayam hanya 1 kali/minggu \\
9 & Satu stel pakain setahun \\
10 & Makan 1-2 kali/hari \\
11 & Tidak sanggup berobat ke puskesmas/poliklinik \\
12 & Sumber penghasilan KK petani berlahan <500m2, buruh tani, buruh nelayan, buruh \\
& bangunan, buruh perkebunan, pekerjaan lainberupah $<$ Rp 600ribu/bulan \\
13 & Pendidikan KK tidak sekolah/tidak tamat SD/tamat SD \\
14 & Tidak memiliki tabungan/barang mudah dijual minimal Rp 500 ribu \\
\hline
\end{tabular}

Sumber : Surat Menteri Desa PDTT No. 126/PRI.00/IV/2020 Tanggal 14 Maret 2020

Pendataan keluarga miskin yang telah ditetapkan tersebut dilakukan oleh relawan yang telah mendapatkan Surat Tugas dari Kepala Desa. Keluarga Penerima Manfaat (KPM) yang Memenuhi Syarat (MS) adalah
KPM yang memenuhi minimal 9 (sembilan) dari 14 (empat belas) kriteria yang ditetapkan oleh Kementrian Sosial Republik Indonesia. 
Dengan adanya 14 kriteria keluarga miskin, relawan desa kesulitan dalam melakukan pendataan di tingkat RT, RW, dan Desa. Selain harus memenuhi minimal 9 (sembilan) kriteria yang ditetapkan, penerima BLT Dana Desa juga tidak boleh menerima bantuan PKH, BPNT, dan kartu pra kerja. Banyak terjadi polemik di lapangan terkait dengan pendataan penerima BLT Dana Desa Tersebut (Mufida, 2020). Oleh sebab itu, keluarlah Surat Direktorat Jendral Pembangunan dan Pemberdayaan Masyarakat Desa No. 9/PRI.00/IV/2020 tanggal 16 April 2020 perihal Petunjuk Teknis Pendataan Keluarga Calon Penerima BLT Dana Desa.

Dalam surat tersebut ditegaskan bahwa kriteria sasaran penerima BLT adalah pertama, keluarga miskin yang terdapat dalam Data Terpadu Kesejahteraan Sosial (DTKS) yang kehilangan mata pencaharian, terdapat anggota keluarga yang berpenyakit kronis/menahun, non PKH, dan non BPNT; Kedua, keluarga miskin yang tidak terdaftar dalam DTKS maka dapat ditambahkan untuk pemutakhiran DTKS; dan Ketiga, calon penerima BLT Dana Desa harus memiliki Nomor Induk Kependudukan (NIK).

Kriteria penerima BLT Dana Desa yang baru ini lebih bersifat umum/luas karena syaratnya adalah keluarga miskin yang masuk DTKS dan non DTKS serta memenuhi kriteria kehilangan mata pencaharian atau pekerjaan, tidak terdata, dan memiliki penyakit kronis. Permasalahan baru yang dihadapi oleh relawan desa adalah sulitnya melakukan sinkronisasi data dengan penerima PKH dan BPNT serta penerima bantuan-bantuan lainnya. Tidak tersedianya data dan informasi yang up to date terkait dengan penerima jaring pengaman sosial ini menyulitkan relawan nantinya saat memvalidasi dan finalisasi penerima BLTDD dalam musyawarah desa khusus. Selain itu, banyak calon penerima BLT-DD yang tidak memiliki NIK.

Polemik pendataan penerima BLT-DD masih saja terus terjadi walapun telah keluar surat dari Dirjen Pembangunan dan pemberdayaan masyarakat desa. Untuk menanggapi hal tersebut, akhirnya keluarlah Surat Direktorat Jendral Pembangunan dan Pemberdayaan Masyarakat No. 10/PRI.00/IV/2020 tanggal 21 April 2020 perihal Penegasan Petunjuk Teknis Pendataan Keluarga Calon Penerima BLT Dana Desa.

Dalam surat tersebut, ada 3 point penegasan terkait dengan penerima BLTDD, yakni pertama, Keluarga miskin yang terdapat dalam Data Terpadu Kesejahteraan Sosial (DTKS) yang kehilangan mata pencaharian, terdapat anggota keluarga berpenyakit kronis/ menahun, non PKH, non BPNT, dan non Kartu Prakerja; Kedua, keluarga miskin non DTKS tetap dapat menerima BLT-DD yang nantinya akan diusulkan dalam pemutakhiran DTKS; dan Ketiga, calon penerima BLT Dana Desa harus memiliki Nomor Induk Kependudukan (NIK).

Masalah yang tetap dihadapi oleh relawan desa adalah masih sulitnya mendapatkan data penerima bantuan $\mathrm{PKH}$ dari dinas sosial kabupaten/kota karena ada penambahan quota penerima. Data masih dalam proses pengajuan ke Kemensos. Selain itu, tidak adanya data terintegrasi dari jaring pengaman sosial ini relawan sulit mendata warga yang menerima bantuan dari kartu pra kerja. BLT Dana Desa harus dibagikan secara cepat dan tepat sasaran, oleh karena itu harus didukung oleh data yang valid dan akurat (KOMPAK, 2020).

Tidak sampai disini, pada tanggal 27 April 2020 Direktorat Jendral Pembangunan dan Pemberdayaan Masyarakat Desa mengeluarkan Surat No. 12/PRI.00/IV/2020 perihal Penegasan BLT Dana Desa. Surat ini menegaskan bahwa (a) Bagi calon penerima manfaat yang telah memenuhi syarat tapi belum memiliki Nomor Induk Kependudukan (NIK) wajib mencantumkan alamat domisili secara lengkap untuk memudahkan proses validasi dan verifikasi; (b) Menegaskan kembali bahwa 14 kriteria keluarga miskin calon penerima manfaat BLT-DD tidak digunakan lagi. 
Permasalahan yang kemudian dihadapi oleh para relawan adalah jumlah calon penerima BLT Dana Desa lebih banyak dari jumlah yang ditentukan oleh Permendesa PDTT No. 6 tahun 2020. Dalam Permendesa PDTT tersebut diatur tentang perhitungan penetapan jumlah penerima manfaat BLT Dana Desa yang mengikuti rumus: (a) Desa penerima Dana Desa kurang dari RP.800.000.000 mengalokasikan maksimal $25 \%$ dari jumlah dana desa; (b) Desa penerima dana desa Rp.800.000.000 sampai dengan Rp.1.200.000.000 mengalokasikan $30 \%$ dari jumlah dana desa; (c) Desa penerima dana desa besar dari Rp.1.200.000.000 mengalokasikan 35\% dari jumlah dana desa.
Permendesa PDTT tersebut memberikan diskresi kepada desa yang jumlah keluarga miskinnya lebih besar dari anggaran yang dialokasikan, yakni desa boleh menambah alokasi setelah mendapat persetujuan pemerintah kabupaten/kota. Namun, untuk di Kabupaten Lima Puluh Kota Provinsi Sumatera Barat sulit untuk mendapatkan persetujuan ini dari pemerintah kabupaten. Terlihat bahwa tidak ada desa/nagari yang memberikan BLT Dana Desa melebihi dari pagu yang telah ditetapkan oleh Permendesa tersebut. Untuk lebih jelasnya permasalahan implementasi kebijakan BLT Dana Desa dapat dilihat pada tabel 2 dibawah ini.

\section{Tabel 2}

Perubahan Sasaran Penerima BLT Dana Desa dan Permasalahannya

\begin{tabular}{|c|c|c|}
\hline Regulasi & Sasaran Penerima BLT & $\begin{array}{l}\text { Permasalahan } \\
\text { Implementasinya }\end{array}$ \\
\hline $\begin{array}{l}\text { Permendesa PDTT } \\
\text { No. } 6 \text { tahun } 2020\end{array}$ & $\begin{array}{l}\text { Keluarga miskin non PKH, non BPNT, } \\
\text { antara lain: } \\
\text { 1. Kehilangan mata pencaharian } \\
\text { 2. Belum terdata (exclussion error) } \\
\text { 3. Mempunyai anggota keluarga yang } \\
\text { rentan sakit menahun atau kronis }\end{array}$ & $\begin{array}{l}\text { Regulasi ini lahir pada tanggal } \\
13 \text { April } 2020 \text { dan pada tanggal } \\
14 \text { April } 2020 \text { keluarlah surat } \\
\text { dari Menteri Desa PDTT No. } \\
\text { 1261/PRI.00/IV/2020 yang } \\
\text { mengatur tentang teknis BLT } \\
\text { Dana Desa. }\end{array}$ \\
\hline $\begin{array}{l}\text { Surat Menteri Desa, } \\
\text { Pembangunan Daerah } \\
\text { Tertinggal, dan } \\
\text { Transmigrasi No. } \\
\text { 1261/PRI.00/IV/2020 }\end{array}$ & $\begin{array}{l}\text { - Keluarga miskin non PKH, non BPNT, } \\
\text { antara lain: } \\
\text { 1. Kehilangan mata pencaharian } \\
\text { 4. Belum terdata (exclussion error) } \\
\text { 5. Mempunyai anggota keluarga yang } \\
\text { rentan sakit menahun atau kronis } \\
\text { - Keluarga miskin minimal memenuhi } 9 \\
\text { kriteria dari } 14 \text { kriteria yang ditentukan } \\
\text { oleh Kementrian Sosial RI } \\
\text { - Keluarga miskin yang masuk dalam } \\
\text { Data Terpadu Kesejahteraan Sosial }\end{array}$ & $\begin{array}{l}\text { - Relawan desa sulit mencari } \\
\text { calon penerima BLT Dana } \\
\text { Desa sesuai dengan kriteria } \\
\text { yang telah ditetapkan. }\end{array}$ \\
\hline $\begin{array}{l}\text { Surat Direktorat Jendral } \\
\text { Pembangunan dan } \\
\text { Pemberdayaan } \\
\text { Masyarakat No. } \\
\text { 9/PRI.00/IV/2020 }\end{array}$ & $\begin{array}{l}\text { (DTKS) yang kehilangan mata } \\
\text { pencaharian, terdapat anggota keluarga } \\
\text { yang sakit menahun/kronis, non PKH, } \\
\text { dan non BPNT. } \\
\text { - Keluarga miskin non DTKS dapat } \\
\text { ditambahkan untuk pemutakhiran } \\
\text { DTKS } \\
\text { - Calon penerima BLT Dana Desa harus } \\
\text { memiliki Nomor Induk Kependudukan } \\
\text { (NIK) }\end{array}$ & $\begin{array}{l}\text { - Relawan desa sulit melakukan } \\
\text { sinkronisasi data dengan } \\
\text { penerima PKH dan BPNT } \\
\text { serta penerima bantuan- } \\
\text { bantuan lainnya } \\
\text { - Banyak calon penerima BLT- } \\
\text { DD yang tidak memiliki NIK }\end{array}$ \\
\hline $\begin{array}{l}\text { Surat Direktorat Jendral } \\
\text { Pembangunan dan } \\
\text { Pemberdayaan } \\
\text { Masyarakat No. } \\
\text { 10/PRI.00/IV/2020 }\end{array}$ & $\begin{array}{l}\text { - Keluarga miskin yang terdapat dalam } \\
\text { Data Terpadu Kesejahteraan Sosial } \\
\text { (DTKS) yang kehilangan mata } \\
\text { pencaharian, terdapat anggota keluarga } \\
\text { berpenyakit kronis/ menahun, non }\end{array}$ & $\begin{array}{l}\text { - Relawan sulit melakukan } \\
\text { pendataan karena Program } \\
\text { Keluarga Harapan }(\mathrm{PKH}) \\
\text { menambah jumlah penerima }\end{array}$ \\
\hline
\end{tabular}


PKH, non BPNT, dan non Kartu Prakerja.

- Keluarga miskin non DTKS tetap dapat menerima BLT-DD yang nantinya akan diusulkan dalam pemutakhiran DTKS

- Calon penerima BLT Dana Desa harus memiliki Nomor Induk Kependudukan (NIK)

- Bagi calon penerima manfaat yang telah memenuhi syarat tapi belum

Surat Direktorat Jendral Pembangunan dan Pemberdayaan Masyarakat No. 12/PRI.00/IV/2020 memiliki Nomor Induk Kependudukan (NIK) wajib mencantumkan alamat domisili secara lengkap untuk memudahkan proses validasi dan verifikasi.

- Menegaskan kembali bahwa 14 kriteria keluarga miskin calon penerima manfaat BLT-DD tidak digunakan lagi. bantuan dan data penerima belum keluar dari Kemensos.

- Relawan juga sulit mendapatkan data penduduk yang menerima bantuan pra kerja.

- Calon penerima BLT Dana Desa lebih besar dari alokasi yang ditetapkan oleh Kementrian Desa.

- Desa sulit mendapatkan persetujuan Pemerintah kabupaten/kota jika ingin menambah alokasi anggaran yang telah ditetapkan Kemendesa.

\subsubsection{Mekanisme Penyaluran BLT Dana Desa}

Dalam Permendesa No.6 tahun 2020 dijelaskan bahwa penyaluran dana desa dilakukan dengan metode non tunai (cashless). Kabijakan ini juga menjadi problematika di lapangan karena keluarga miskin penerima manfaat BLT-DD kesulitan untuk membuka rekening tabungan di bank karena berada di lokasi yang jauh dari kota serta dibutuhkan biaya besar untuk ke bank.

Kebijakan ini pun berubah ketika banyak kepala desa yang protes dan akhirnya keluarlah (a) Surat Direktorat Jendral Pembangunan dan Pemberdayaan Masyarakat No. 10/PRI.00/IV/2020 tanggal 21 April 2020 (b) Instruksi Menteri Dalam Negeri RI No. 3 tahun 2020 tentang Penanggulangan COVID-19 di Desa Melalui Anggaran Pendapatan dan Belanja Desa tanggal 21 April 2020; dan (c) Surat Direktorat Jendral Pembangunan dan Pemberdayaan Masyarakat No. 12/PRI.00/IV/2020 tanggal 27 April 2020. Semua regulasi tersebut diatas menegaskan bahwa penyaluran BLT-Dana Desa dapat dilakukan secara tunai (cash) dan non tunai (cashless) kepada penerima manfaat. Penyaluran secara tunai dengan tetap dan harus memperhatikan protokol kesehatan yaitu menjaga jarak, menghindari kerumunan, dan memakai masker.

Dengan adanya surat ini terjawablah kegelisahan kepala desa terkait dengan mekanisme penyaluran dana desa kepada penerima manfaat. Hal ini tentu dengan memperhatikan kondisi geografis yang tidak sama disetiap daerah di Indonesia.

\subsection{Faktor Inkosistensi Regulasi \\ Inkonsistensi regulasi dalam} penyaluran BLT-DD ini terlihat sejak awal kebijakan BLT-DD ini dikeluarkan. Hal ini terlihat dari banyaknya regulasi yang dikeluarkan oleh pemerintah, baik yang mengatur tentang sasaran penerima, mekanisme penyaluran, jangka waktu pelaksanaan, dan penyaluran Dana Desa. Regulasi BLT Dana Desa yang terus berubah ini membuat bingung pemerintahan di level bawah, yakni pemerintahan desa sebagai implementor dari kebijakan BLTDana Desa. Menurut Edwards, jika implementasi kebijakan ingin berlangsung efektif maka perintah-perintah pelaksanaan harus konsisten dan jelas (Winarno, 2008). Adapun regulasi-regulasi tersebut ada dalam tabel 3. 
Tabel 3.

Regulasi yang Mengatur Tentang BLT-Dana Desa

\begin{tabular}{|c|c|c|}
\hline No & $\begin{array}{c}\text { Tanggal } \\
\text { Ditetapkan }\end{array}$ & Nama Regulasi \\
\hline 1 & 13 April 2020 & $\begin{array}{l}\text { Peraturan Menteri Desa No. } 6 \text { Tahun } 2020 \text { Tentang Perubahan Atas } \\
\text { Peraturan Menteri Desa, Pembangunan Daerah Tertinggal, dan } \\
\text { Transmigrasi No. } 11 \text { Tahun } 2019 \text { Tentang Prioritas Penggunaan Dana Desa } \\
\text { Tahun } 2020\end{array}$ \\
\hline 2 & 14 April 2020 & $\begin{array}{l}\text { Surat Menteri Desa PDTT No. 1261/PRI.00/IV/2020 Tentang } \\
\text { Pemberitahuan Penggunaan Dana Desa. }\end{array}$ \\
\hline 3 & 16 April 2020 & $\begin{array}{l}\text { Surat Direktorat Jendral Pembangunan dan Pemberdayaan Masyarakat } \\
\text { Desa No. 9/PRI.00/IV/2020 Tentang Petunjuk Teknis Pendataan Keluarga } \\
\text { Calon Penerima BLT Dana Desa }\end{array}$ \\
\hline 4 & 20 April 2020 & $\begin{array}{l}\text { Peraturan Menteri Keuangan RI No. 40/PMK.07/2020 Tentang Perubahan } \\
\text { Atas Peraturan Menteri Keuangan No. 205/PMK.07/2019 Tentang } \\
\text { Pengelolaan Dana Desa. }\end{array}$ \\
\hline 5 & 21 April 2020 & $\begin{array}{l}\text { Surat Direktorat Jendral Pembangunan dan Pemberdayaan Masyarakat No. } \\
\text { 10/PRI.00/IV/2020 Tentang Penegasan Petunjuk Teknis Pendataan } \\
\text { Keluarga Calon Penerima BLT Dana Desa. }\end{array}$ \\
\hline 6 & 21 April 2020 & $\begin{array}{l}\text { Instruksi Menteri Dalam Negeri RI No. } 3 \text { Tahun } 2020 \text { Tentang } \\
\text { Penanggulangan Corona Virus Disease } 2019 \text { (COVID-19) di Desa Melalui } \\
\text { Anggaran Pendapatan dan Belanja Desa }\end{array}$ \\
\hline 7 & 27 April 2020 & $\begin{array}{l}\text { Surat Direktorat Jendral Pembangunan dan Pemberdayaan Masyarakat No. } \\
\text { 12/PRI.00/IV/2020 perihal Penegasan BLT Dana Desa }\end{array}$ \\
\hline 8 & 8 Mei 2020 & $\begin{array}{l}\text { Surat Direktorat Jendral Bina Pemerintahan Desa No. 188.32/2236/BPD } \\
\text { perihal penambahan kode output dan satuan output kegiatan }\end{array}$ \\
\hline 9 & 15 Mei 2020 & $\begin{array}{l}\text { Instruksi Menteri Desa, Pembangunan Daerah tertinggal dan Transmigrasi } \\
\text { No. } 1 \text { tahun } 2020 \text { Tentang Percepatan Penyaluran BLT-Dana Desa }\end{array}$ \\
\hline 10 & 19 Mei 2020 & $\begin{array}{l}\text { Peraturan Menteri Keuangan RI No. 50/PMK.07/2020 Tentang Perubahan } \\
\text { Kedua Atas Peraturan Menteri Keuangan No. 205/PMK.07/2019 Tentang } \\
\text { Pengelolaan Dana Desa }\end{array}$ \\
\hline 11 & 16 Juni 2020 & $\begin{array}{l}\text { Peraturan Menteri Desa No. } 7 \text { Tahun } 2020 \text { Tentang Perubahan Kedua Atas } \\
\text { Peraturan Menteri Desa, Pembangunan Daerah Tertinggal, dan } \\
\text { Transmigrasi No. } 11 \text { Tahun } 2019 \text { Tentang Prioritas Penggunaan Dana Desa } \\
\text { Tahun } 2020\end{array}$ \\
\hline 12 & 28 September 2020 & $\begin{array}{l}\text { Peraturan Menteri Desa No. } 14 \text { Tahun } 2020 \text { Tentang Perubahan Ketiga } \\
\text { Atas Peraturan Menteri Desa, Pembangunan Daerah Tertinggal, dan } \\
\text { Transmigrasi No. } 11 \text { Tahun } 2019 \text { Tentang Prioritas Penggunaan Dana Desa } \\
\text { Tahun } 2020\end{array}$ \\
\hline 13 & 5 Oktober 2020 & $\begin{array}{l}\text { Surat Menteri Desa, Pembangunan Daerah Tertinggal, dan Transmigrasi } \\
\text { No. 2724/PRI.00/X/2020 Perihal Penyaluran BLT- Dana Desa Sampai } \\
\text { Desember } 2020\end{array}$ \\
\hline
\end{tabular}

Sumber: Analisis Peneliti, 2021

Dari tabel 3 diatas terlihat bahwa begitu banyak regulasi yang dikeluarkan oleh pemerintah, terlihat bahwa dalam bulan April saja ada 7 (tujuh) regulasi yang dikeluarkan. Hingga penyaluran BLT-Dana Desa ini salur sampai dengan bulan Desember 2020, ada 13 (tiga belas) regulasi yang dikeluarkan oleh pemerintah pusat. Regulasi yang begitu banyak dan terus berubah menyebabkan pemerintah desa sulit untuk mengambil tindakan karena setiap regulasi yang keluar tidak konsisten.
Kebijakan penyaluran BLT-Dana Desa yang semula hanya 3 bulan (April, Mei, Juni) diperpanjang menjadi 6 bulan (Juli, Agustus, September), dan kemudian diperpanjang lagi menjadi 9 bulan (Oktober, November, Desember). Inkonsistensi regulasi terkait dengan penyaluran BLTDana Desa menjadi 3 fase ini menyulitkan pemerintahan desa dalam melakukan refocusing anggaran dana desa yang kemudian berdampak pada berkurangnya jumlah penerima BLT-Dana Desa. Hal ini 
terjadi karena Dana Desa telah digunakan untuk kegiatan Desa Aman COVID-19, stunting, dan Padat Karya Tunai Desa (PKTD).

\subsection{Faktor Teknis}

Faktor teknis yang dimaksud dalam penelitian ini adalah terkait dengan proses penyaluran BLT-Dana Desa. Proses yang harus ditempuh oleh pemerintahan desa dapat dikatakan cukup panjang hingga mencapai ke tahap salur. Hal yang pertama kali yang harus ditempuh oleh pemerintahan desa adalah menetapkan SK relawan desa. Setelah SK ini ditetapkan, maka relawan tersebut mulai melakukan pendataan calon penerima BLT-Dana Desa ditingkat RT, RW, dan desa. Pendataan ini didasarkan pada kriteria yang telah ditetapkan oleh regulasi. Proses pendataan ini cukup memakan waktu yang lama karena berubahnya kriteria penerima.

Setelah relawan desa mendapatkan data calon penerima BLT-Dana Desa ini, maka dilaksanakanlah musyawarah desa khusus untuk memferivikasi dan memfinalisasi data yang ada. Proses ini juga melalui perdebatan yang panjang antara relawan desa, pemerintahan desa, dan Badan
Permusyawaratan Desa (BPD) terkait dengan calon penerima BLT-Dana Desa yang akan ditetapkan. Jika data calon penerima tersebut sudah mencapai kata mufakat, maka ditetapkanlah calon penerima tersebut melalui SK Kepala Desa. Akan tetapi, jika belum mendapatkan kata sepakat maka calon penerima BLT-Dana Desa harus dilakukan pendataan kembali.

Jika penerima BLT-Dana Desa tahun 2020 telah ditetapkan, pemerintahan nagari bersama dengan BPD melakukan pembahasan terkait dengan refocusing anggaran. Hal ini dilakukan karena BLTDana Desa tidak dianggarkan sebelumnya dalam APBDes. Sehingga untuk mengalihkan kegiatan yang telah ditetapkan sebelumnya dilakukan pembahasan bersama BPD. Jika pembahasan refocusing ini selesai, pemerintahan nagari melakukan perubahan penjabaran APBDes yang ditetapkan melalui Peraturan Kepala Desa. Setelah semua rangkaian proses tersebut selesai, maka pemerintahan desa dapat menyalurkan BLT-Dana Desa. Tahapan penyaluran tersebut dapat dilihat pada gambar 1.

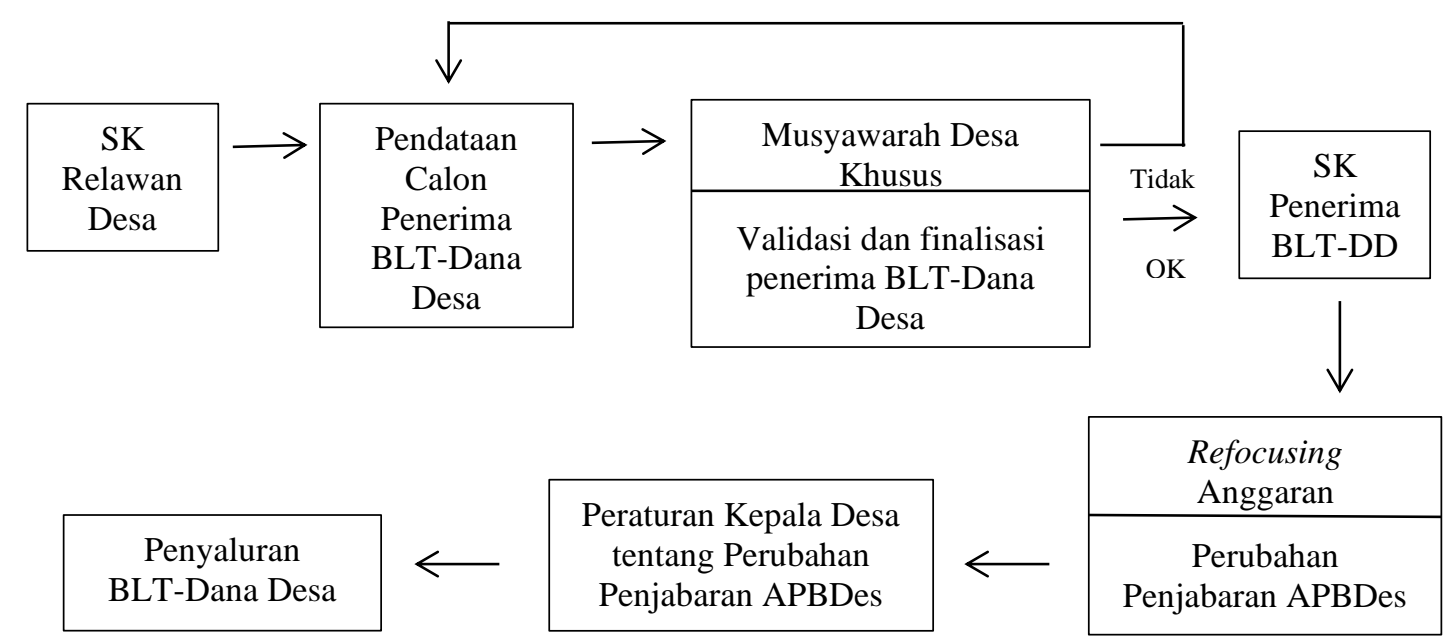

Gambar 1.

Proses penyaluran BLT-Dana Desa Ditinjau dari Beberapa Regulasi

Sumber: Analisis Peneliti, 2021

\section{Kesimpulan}

Faktor yang mempengaruhi kinerja implementasi dalam penyaluran BLT-Dana
Desa adalah Pertama, faktor Kejelasan isi kebijakan. Dengan selalu berubahnya kriteria calon penerima BLT-Dana Desa, 
relawan desa sulit melakukan pendataan calon penerima BLT-Dana Desa. Selain itu, relawan juga dihadapkan dengan adanya batasan jumlah calon penerima BLT-Dana Desa berdasarkan persentase dana desa yang diterima oleh desa. Walaupun dari sisi regulasi memberikan diskresi untuk penambahan calon penerima BLT-Dana tersebut, tetapi desa sulit mendapatkan persetujuan dari Bupati.

Kedua, Faktor Inkonsistensi Regulasi. Regulasi yang terus berubah menyulitkan pemerintah desa dalam implementasi penyaluran BLT-DD. Regulasi yang terus berubah terkait dengan kriteria calon penerima BLT-Dana Desa, mekanisme penyaluran BLT-Dana Desa, dan juga terkait dengan jangka waktu penyaluran dana desa.

Ketiga, Faktor Teknis. Proses penyaluran BLT-Dana Desa yang cukup panjang membuat pemerintah desa tidak dapat menyalurkan BLT-Dana Desa tepat pada waktunya karena setiap proses tahapan memakan waktu yang cukup lama. Proses yang memakan waktu tersebut adalah pendataan, musyawarah desa khusus dalam verifikasi dan finalisasi calon penerima BLT-Dana Desa, dan pada saat pembahasan refocusing anggaran dengan BPD.

\section{Daftar Pustaka}

Agustino, L. (2020). Analisis Kebijakan Penanganan Wabah Covid-19: Pengalaman Indonesia. Borneo Administrator, 16 (2), 253-270. http://samarinda.lan.go.id/jba/index. $\mathrm{php} / \mathrm{jba} /$ article/view/685

Amiruddin, A. (2020). Otonomi Desa Ditengah Pandemi Covid 19: Senarai kekhawatiran. In Hukum dan Politik: Regulasi yang Memuliakan Martabat manusia (pp. 62-76). Sanggar Inovasi Desa.

Hariandja, T. R., \& Budiman, N. T. (2020). Transparansi Dalam Pelaksanaan Bantuan Langsung Tunai (BLT) Dana Desa. IJLIL: Indonesian Journal of Law and Islamic Law, 1 (3), 263-277. https://ijlil.iain- jember.ac.id/index.php/ijl/article/vie w/86/17

Inayah, G. (2020). Ada Apa dengan Covid19? Mediakom Kemenkes RI, 28-29.

KOMPAK. (2020). Panduan Pendataan BLT-Dana Desa.

Maun, C. E. . (2020). Efektivitas Bantuan Langsung Tunai Dana Desa Bagi Masyarakat Miskin Terkena Dampak Covid-19 di Desa Talaitad Kecamatan Suluun Tareran Kabupaten Minahasa Selatan. Politico, 9 (2), 1-16. https://ejournal.unsrat.ac.id/index.ph p/politico/article/view/30702

Mufida, A. (2020). Polemik Pemberian Bantuan Sosial di Tengah Pandemic Covid 19. ADALAH: Buletin Hukum Dan Keadilan, 4 (1), 159-166. http://www.journal.uinjkt.ac.id/inde x.php/adalah/article/view/15669

Novianty, I., Setiawan, I., Afiyanti, F., Syarief, E., Gunawan, A., Sudrajat, S., \& Djatnika, D. (2020). Praktik Penganggaran Dan Penyaluran Bantuan Dana Desa di Masa Pandemi Covid-19 (Studi Kasus Pada Desa Sariwangi Kabupaten Bandung Barat). Mewujudkan Daya Saing Dan Kemandirian Bangsa Melalui Peningkatan Inovasi, Penelitian, Dan Pengabdian Kepada Masyarakat, 1583-1592. http://www.openjournal.unpam.ac.id /index.php/Senan/index

Nugraheny, D. E. (2020). Ini Sebaran Pasien Pasitif Covid-19 di 31 Provinsi Per 30 Maret. https://nasional.kompas.com/read/20 20/03/30/17193651/ini-sebaranpasien-positif-covid-19-di-31provinsi-per-30-maret?page $=$ all

Rahmansyah, W., Qadri, R. A., Sakti, R. R. A., \& \& Ikhsan, S. (2020). Pemetaan Permasalahan Penyaluran Bantuan Sosial untuk Penanganan Covid-19 di Indonesia. Pajak Dan Keuangan Negara, 2 No. 1, 90-102. http://www.jurnal.stan.ac.id/index.p $\mathrm{hp} / \mathrm{pkn} /$ article/view/995 
Sari, A., Widayat, W., \& Zulkifli, Z. (2020).

Dampak Penggunaan Dana Desa Dalam Masa Pandemi Covid-19 Tahun 2020 (Studi Kasus Pada Desa banyuasin Kembaran Kecamatan Loano, Kabupaten Purworejo) [STIE Widya Wiwaha]. http://eprint.stieww.ac.id/1430/

Silalahi, U. (2010). Metode Penelitian Sosial (A. Gunarsa (ed.); Kedua). PT. Refika Aditama.
Subarsono, A. (2008). Analisis Kebiijakan Publik: Konsep, Teori, dan Aplikasi (2nd ed.). Pustaka Pelajar.

Sugiyono. (2005). Memahami Penelitian Kualitatif (Kesatu). CV. Alfabeta.

Winarno, B. (2008). Kebijakan Publik: Teori dan Proses (2nd ed.). MedPress.

Yandra, A. (2016). E-goverment dengan memanfaatkan informasi. POLITIK, 12(1), 1769. 